$\underline{\mathbf{P}-185}$

\title{
Alpha Amalyse Inhibitory Activity of Rhodamnia Cinerea
}

\author{
M Chinnappan S*, George A, Md Akir MH, Mohtar NH
}

Biotropics Malaysia Berhad, Lot 21, Jalan U1/19, Section U1, Hicom-Glenmarie Industrial Park, 40150 Shah Alam, Selangor, Malaysia; E-mail: sasikala.c@biotropicsmalaysia.com

Food high in carbohydrate causes a rise in glycemic index in diabetes type II patients. Glycemic index in pre diabetic and diabetic individuals can be managed by modulating alpha amylase inhibitors. Alpha-amylase is an enzyme that hydrolyses alpha-bonds of large alpha-linked polysaccharides such as starch and glycogen yielding glucose and maltose. By inhibiting alpha amalyse activity the polysaccharides hydrolysis process will be inhibited or delayed therefore alpha amalyse inhibitors help to maintain postprandial glycemic index. Water extract of Rhodamnia cinerea leaves, a commonly found tree in secondary forests of Malaysia was tested for alpha amylase inhibition. The in- vitro inhibitory activity demonstrated that water extract of Rhodamnia cinerea leaves as a potent alpha amalyse inhibitor. The water extract inhibited alpha amalyse activity by $12.6 \%$, $32.8 \%, 93.1 \%$ and $97.1 \%$ at concentrations of $0.78 \mu \mathrm{g} / \mathrm{mL}, 3.13 \mu \mathrm{g} / \mathrm{mL}, 12.5 \mu \mathrm{g} / \mathrm{mL}$ and $50 \mu \mathrm{g} / \mathrm{mL}$ respectively. The same extract was tested for Acute Starch Tolerance Test (STT), an in vivo model using rats for evaluation of the effect of alpha amylase inhibitors on glycemia. The water extract of Rhodamnia cinerea leaves reduced glycemic response to starch by $17.9 \%$ and $38.5 \%$ at the dose of $50 \mathrm{mg} / \mathrm{kg}$ (area under the curve $0-120 ; \mathrm{p}<0.001$ ) and the dose of $200 \mathrm{mg} / \mathrm{kg}$ of body weight (area under the curve $0-120 ; \mathrm{p}<0.001)$ respectively. With regards to time-points, this effect was statistically significant for doses of $50 \mathrm{mg} / \mathrm{kg}$ and $200 \mathrm{mg} / \mathrm{kg}$ body weight at 15,30 and $60 \mathrm{~min}$ and remained statistically significant at $90 \mathrm{~min}$ at the dose of 200 $\mathrm{mg} / \mathrm{kg}$ body weight. 